\title{
Potential Output and the Recent Productivity Decline
}

\author{
JOHN A. TATOM
}

15TENTIAL output refers to the real gross national product (GNP) that is produced if the economy operates under high-employment conditions. Measures of potential output depend on measures of available resources, such as capital and labor, and reliable estimates of the relationship between national output and the employment of resources.

Since 1973, the growth of productivity (measured as output per unit of labor) has slowed substantially (see chart 1), raising doubt about the relationship of input to output and, therefore, the measurement of the nation's potential GNP. This issue is of considerable importance as it bears on the traditional concern over the degree of resource underitilization and the assoerated output losses in the economy. An accurate assessment of potential output is essential to determine the expected gain in output from a policy intended to achieve full employment. The relationship between resource supplies and potential output also is important in analyzing the output gain from supply-side policies to increase the supply of resources through increased work, saving and investment.

This Bank's measure of potential output differs from others in that it provides direct estimates of the effects of labor force growth, capital accumulation and changes in the relative cost of energy resources on productivity and economic capacity. ${ }^{x}$ The stability of the input-output relationship on which this measure is based, and its ability to fully account for the unusual productivity developments during the last decade, provided support for the credibility of past estimates. Since energy costs have increased

\footnotetext{
"The original neasures used by this Bank and the methods of their construction are explained in Robert $H$. Rasche and John $A$. Tatom, "Energy Resonces and Potential GNP" this Review (June 1977), 10. 10-24. The theoretical basis for the energy price effect is developed in Robert H. Rasche and John A. Tatom, "The Effects of the New Energy Regime on Economic Capacity Production and Prices," this Review (May 1977), pp. 2-12. These
}

dramatically since 1978 , it is important to verify that the earlier empirical results are consistent with recent productivity experience, as well as to assess the impact of this shock on potential GNP. Also, recent revisions of the GNP accounts incorporate new information on output and involve some conceptual changes that require revisions in potential GNP measures. In addition, since 1977 some modifications have occurred in the methods used by this Bank to measure potential output. The revisions and modifications are described below.

\section{ENETG PRICI $5 \mathrm{HOCKS}$ AND

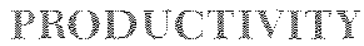

A sharp increase in the relative price of energy causes a reduction in the output (productivity) of existing labor and capital resources, or economic capacity. The particular channels through which this change occurs vary from firm to firm, but include changing production methods to reduce the use of higher-cost energy, the closing of plants rendered unprofitable, reduced optimal and actual use of existing facilities, and the diversion of labor and capital resources to uses that economize on highercost energy. These changes result in less output being produced despite an initially unchanged availability of domestic capital and labor resources. As a result, measures of productivity such as output per workex, per hour, or per unit of capital, decline. The rise in energy prices also induces a percentage increase in the nominal prices of output equal to the percentage decline in productivity or potential out-

hypotheses are further elaborated, and intermational evidence supporting them are presented in Rasche and Tatom, "Energy Price Shocks, Aggregate Supply and Monetary Policy: The Theory and International Evidence," in Karl Branner and Allan H. Meltzer, eds., Supply Shocks, Incentices and National Wealth, Carnegie-Rochester Conference Series on Public Policy, Vol. 14 (1981), pp. 9-93. 
Output per Hour (Private Business Sector)

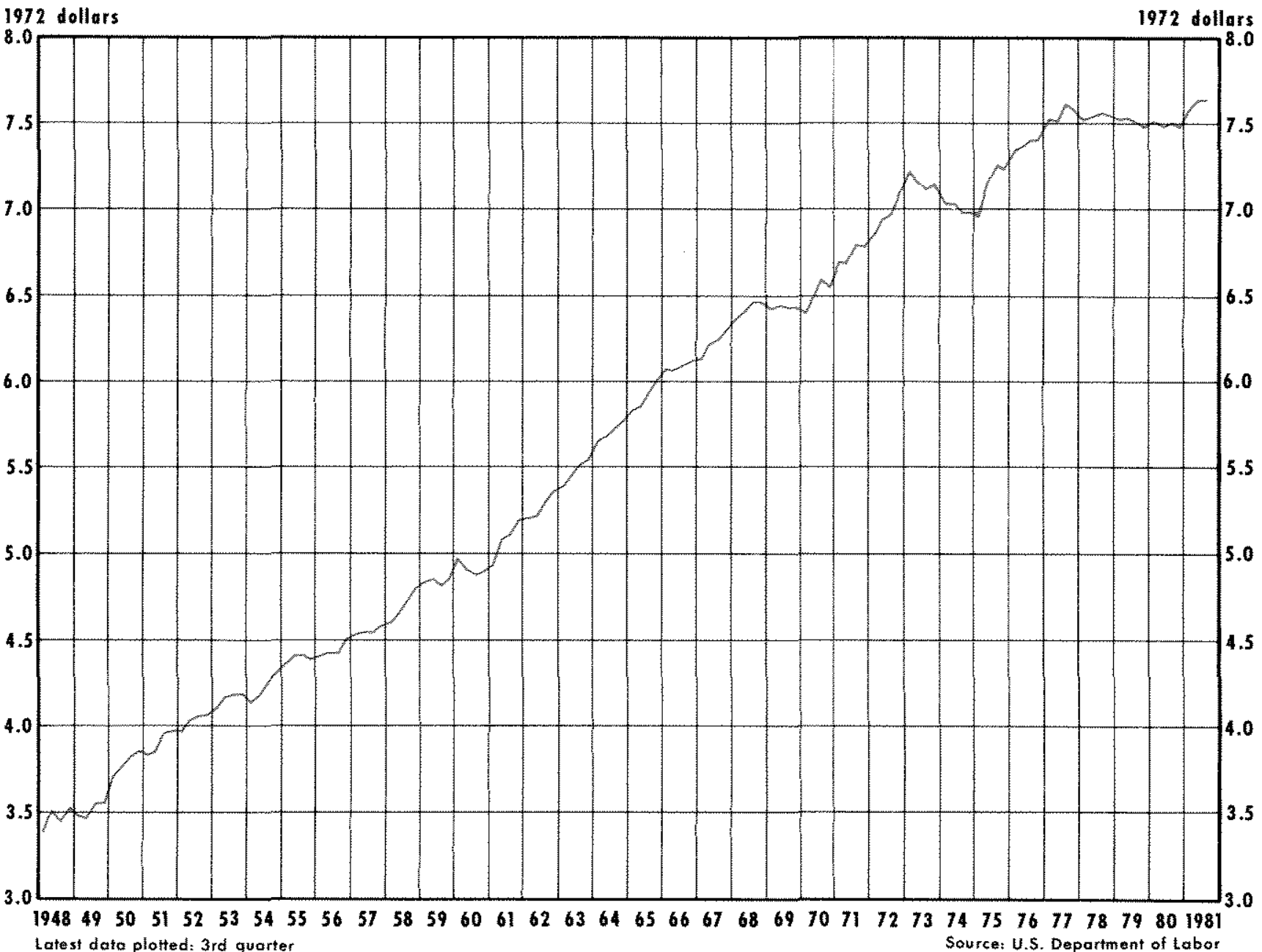

put, since less output is producible tor a given supply of money.

In addition, the decline in productivity shifts the demand for labor and capital resources down. In the short run, these shifts are reflected in a fall in the real wages of workers and a decline in the value of existing plant and equipment relative to its replacement cost. Over a longer period, the capital stock available per worker will decline from the level that would otherwise have occurred, so that the long-run decline in potential output, labor productivity and real wages is larger than the initial decline.

The effect of a rise in the relative price of energy on production is manifested in a production function approach through reductions in inputs (especially reduced energy usage), or through changes in productive efficiency or capacity that are "disembodied," that is, not associated with changes in the use of physical inputs such as labor, capital or energy. Earlier studies have provided an unbiased estimate of the effect of a rise in the relative price of energy on output that supports the energy pricel economic capacity hypothesis. ${ }^{2}$ Before re-examining

${ }^{2}$ An elaborate revew of other analyses of energy price effects on the econony is presented in Rasche and Tatom, "Energy Price Shocks, Agsgregate Supply," pp. 16-33. A more recent criticue of the analysis here is Frnst R. Berndt, "Energy Price Increases and the Productivity Slowdown in United States Manufacturing," Federat Reserve Bank of Boston, The Dertine in Producticity Grothth, Conference Series No. 22 (June 1980), 1p. 60-89.

Berndt finds no effect of higher energy prices on manufacturing productivity, in contrast to the evidence in Joln A. Tatom, 
the production function estimates, however, it is useful to review recent revisions in the data series used to estimate potential GNP.

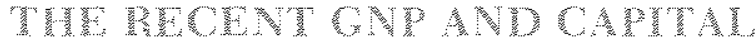

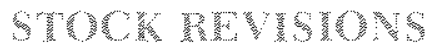

From time to time, the U.S. Department of Commerce announces major revisions in the GNP accounts based on new source data, new estimating procedures and definitional or conceptual changes. The latest revision was published in December 1980.3

The basis of the recent revision was new information from the 1972 input-output tables, the 1977 economic censuses of various industries, and information from the 1973 and 1976 Taxpayer Compliance Measurement Program. In addition, GNP was redefined to include the reinvested earnings of incorporated foreign affiliates of U.S. direct investors and to exclude those of incorporated U.S. affilm iates of foreign direct investors. The redefinition of GNP primarily affects the measure of income originating in the rest of the world, with little effect of the measurement of output from the nation's private sector.

Another important part of the revision was in gross private domestic investment. The revision of this measure was largely due to revised estimates of producer durable equipment investment. At the same time, a conceptual change occured, shifting the output and investment in hotels and motels from the residential to the nonresidential sector. Except for the treatment of reinvested eamings abroad, however, the revisions of GNP primarily affect data beginning in 1968.

"The Productivity problem," this Recte (September 1979), pp. 13-14. Unfortunately, as Berndt notes, a matom share of energy resoufees is classified as ma materials in his data set, and his analysis can be easily extended to show that most of the productivity dedine he analyzes is due to ar inerease in the relative price of these "raw materials." Berndt also clams to show that an observed decline in the whe of clams on existing physical calpital relative to the replacement cost, as hypothesized athoes is atho not explaned by energy pros increatses. Hi theoretict analysis is flawed by the omission of a significant ontput elfect that substantially rasses the magnitude of his estimate of the ellect of higher energy prices on the value of existing catzitat.

"For a discussion of these revisions, see Keith M. Carlson "Recent thevisions of GNP" this Relict (Math 1981),pp. 27 32, and

"The Vational Income atrd Prodnct Acounts of the Uryted States: An Introduction to the Revised Fstimates for 1929-80"

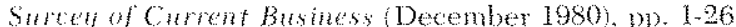

\section{Table 1}

Revisions in Real Net Capital Stock and Private Business Sector Output (selected years) ${ }^{1}$

\begin{tabular}{|c|c|c|}
\hline Yed & 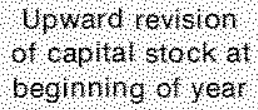 & 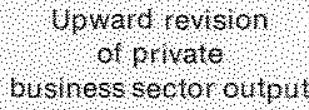 \\
\hline 1950 & $21 \%$ & $0,3 \%$ \\
\hline 1955 & 20 ह & ब \\
\hline 1960 & 18 & 15 \\
\hline 1965 & 20 & 02 \\
\hline 1970 & 29 & 02 \\
\hline 1975 & 49 & 28 \\
\hline
\end{tabular}

Thioures are the bercentage horease of 1980 revised date over data avallable 1097

The new source information affected measures of the nation's capital stock as well, especially after 1967. The reclassification of hotel and notel capital stocks is the primary source of changes in the measures prior to 1967 . While the level of the nation's net nonresidential private capital stock (constant prices) was raised because of these chinges, the growth rate was changed very little prior to 1973 . For example, the revised data show a 4.2 percent anmual rate of growth from 1948 to 1968 , the same as earlier data. From 1968 to 1973, the revised data indicate growth of the net capital stock at a 4.4 percent rate, up from 4.0 percent in the earlier data. From 1973 to 1978 , the revised capital stock shows that capital formation slowed to a 3.1 percent rate. Earlier data show the same extent of slowing in capital formation to a 2.7 percent rate from 1973 to 1978 . As a result, the conclusion of ealier research that capital formation slowed subsequent to 1973 , especially when measured relative to labo: force growth, has been unaffected by the revisions. The rate of growth of the capital stock, however, has been somewhat faster since 1968 than earlier estinates showed; this could affect earlier estmates of input-output relationships.

Table 1 shows the extent of both the upward revision of the constant-dollar net stock of fxed nonresidential private capital at the beginning of the year and the private business sector output for data used in 1977 as compared with the recent revisions. The capital stock has been revised upward relatively more than output. 


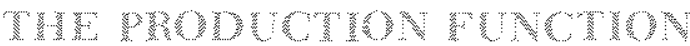

The basis of this Bank's potential output estimates is a production function for private business sector (PBS) output that relates output to hours of employment, the atilization of capital, and energy. Available measures of energy tend to be broken down by types of users, such as residential, commercial and industrial. No energy measures exist that are detalled by production $\mathrm{vs}$. consumption use by households, or by producing sectors like the manufacturing and private business sector. Since energy measures compatible with existing data on sectoral output and employment of labor and capital do not exist, a "first-order condition" for energy employ. ment is used to eliminate the quantity of energy from the production function, replacing it with the relative price of energy. Formally, the estimated equation is of the form,

(1) $\ln X_{t}=\beta_{0}+\beta_{1} \ln l_{t}+\beta_{0} \ln k_{t}+\beta_{3} \ln \left(\operatorname{Pe} / P_{p_{+}}+\beta_{4} \ln t\right.$,

where $X_{t}$ is PBS output in period $t, h_{t}$ is hours of all persons, $k_{t}$ is the utilized net nonresidential capital stock (constant prices), the product of the Federal Reserve Board manufacturing capacity utilization rate and the capital stock in place at the end of period $\mathrm{t}-\mathrm{I}$, and $\mathrm{Pe} / \mathrm{P}$ is the relative price of energy, found by deflating the producer price index for fuel, power and related products by the implicit price deflator for private business sector output. The term is a time trend intended to capture the rate of technology change. When equation 1 is derived from a CobbDouglas production function, the $\beta$ s in equation 1 are related to the output elasticities of the inputs, as shown in table 2 .

Estimates of the amnual production function using the revised data for the periods 1949-73, 1949-75 and $1949-80$ are shown in table $3{ }^{4}$ There are three notewothy revisions in the estimates. Finst the coefficient on the relative price of energy and estimate of the output elasticity of energy are smaller in absolute value, though not in a statistically significant sense, with the new measures of ontput and

\footnotetext{
"The ofdinary least squares (OLS) estimates of the coeffeients in thble 3 itre trath identical but the Durbin-Watson statistics are 1.28, 1.35, and 1.37 for the 19.49-73, 1949-75, and 1949-80 perods, respectivety, To dueck whether this atocorelated errom pat tern results from the omission of significme latged in put effects on antput, one and two poriod lags on the ingut waribles are aded to the enuations in table 3 and their ols contemats. When this is clone, the coefficients are not ignificant, the Durbinuhation statistic does not change and the estimate of $p$ shown in tuble 3 is not rediced.
}

Table 2

\section{Indirect Least Squares Estimation of a Cobb-Douglas Production Function}

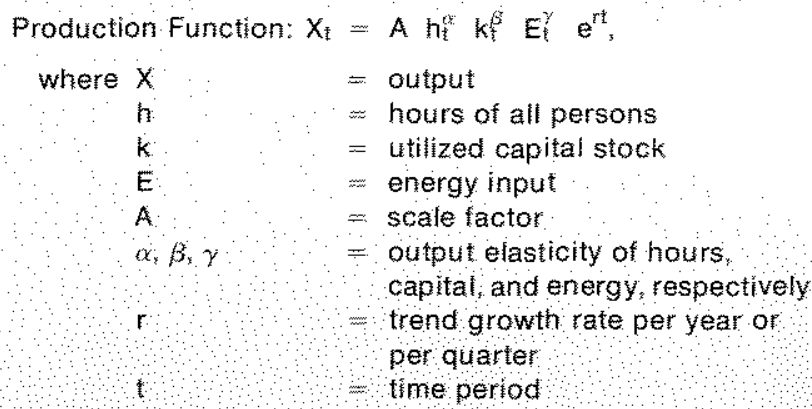

Firstorder Condition for Energy Pe/P $\quad h X / E$

Where Pep - the price of energy relative to the price of output

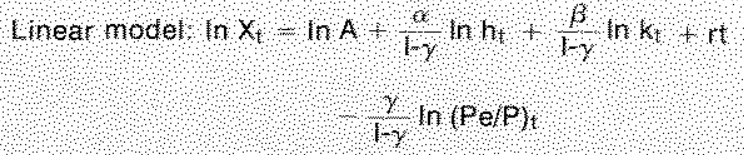

capital. In the ealier estimation for 1949-73 and $1949-75, \hat{\gamma}$ is 11.7 percent $(t=1.92)$ and 12.0 percent $(t=5.66)$, respectively. Second, the autocorrelation adjustment, $\hat{\rho}$, is smaller than before 0.63 for the 1949-75 period). Finally, the estimates for the period 1949-73 are even closer to those for the longer sample periods than they are with the earlier estimates. In the earlier estimations, there are no significant differences in the coefficient estimates across periods, but $\hat{x}$ is 1.2 percent per year and $\hat{x}$ is 58.9 percent in the 1949-73 sample period; these are 1.6 percent and 64.9 percent, respectively, in the earlier estimation for the 1949-75 sample period.

An important hypothesis that was supported in earlier work is rejected using the revised data. A slowing in the time trend for technological change beginning in 1967 could not be rejected earlier. For all thee sample periods in table 3 , this hypothesis is rejected. A time-trend variable with a value of zero to 1966 , then increased by one each year from 1966 on, was added to each equation estimated in table 3 . The t-statistics for the slower trend variable are 
Table 3

Production Function Estimate for the U.S. Private Business Sector

\begin{tabular}{|c|c|c|c|}
\hline & 194973 & 194975 & 194980 \\
\hline 80 & $(3,3480)$ & $(10,70)$ & $\begin{array}{l}1,497 \\
(13251\end{array}$ \\
\hline$B^{\prime}$ & $(9656)^{\circ}$ & 107302 & $\begin{array}{c}0720) \\
(1307)\end{array}$ \\
\hline B. & 0.6716 & 4049698 & $\begin{array}{l}02799 \\
(508)^{\circ}\end{array}$ \\
\hline 13 & $\begin{array}{l}0.0704 \\
(1.00)\end{array}$ & 0.0875 & $(-0.0953$ \\
\hline 16 & 4784 & 49018 & $(9,48)$ \\
\hline 0 & $\begin{array}{l}0.6432 \\
(9.57)\end{array}$ & $\begin{array}{l}06715 \\
(430)\end{array}$ & $\begin{array}{l}0.6574 \\
(1458)\end{array}$ \\
\hline 1 & 40,490 & $(0,2481$ & $\begin{array}{l}0.2556 \\
(5.31)\end{array}$ \\
\hline & & 480895 & $(4689)$ \\
\hline 8 & $\begin{array}{l}0.075 \\
6.107\end{array}$ & $\begin{array}{l}0.0767 \\
10.24 \%\end{array}$ & 10.0962 \\
\hline n? & 0,97 & 097 & 097 \\
\hline sf & 00091 & 00099 & 00102 \\
\hline bw & 203 & 193 & 196 \\
\hline ?ि. & 044 & 039 & 039 \\
\hline
\end{tabular}

$-1.67,-1.50$, and -1.41 , for the 1949-73, 1949-75, and $1949-80$ periods, respectively. The slowing is not statistically significant at a 5 percent level in any of these periods. ${ }^{5}$ In addition, a test for an optimal point for a trend break using a minimum standard error criterion fails to reveal a point superior to 1967 . There is no evidence then for a slowdown in productivity growth dive to disembodied factors influencing the trend.

The new estimates do not alter any of the other earlier conclusions. In particular, the status of a number of hypotheses tested earlier has been unchanged because of the changes in the private business sector concepts and the new measures. For example, tests of the Cobb-Donglas restriction yield the rejection of a translog specification of the production function.

"This result held betore the recent revisions as well. See Rasche and Tatom, "Energy price Shocks, Aggregate Sumply," p. 25.
The output elasticity of hours during the three periods is not significantly different from the share of labor in total costs during each of the three periods. This is extremely important as the CobbDouglas production function implies a price elasticity for energy demand that may be biased upward. While this would not yield a bias in the estimated effect of energy prices on output, it would yield an upward-biased estimate of $\gamma$ and a downward-biased estimate of $\alpha$. There is no evidence of such a bias. The $t$-statistics for the equality of the $\hat{\alpha}$ estimate and the actual share of labor in each period are -0.22 , 0.27 , and -0.08 , respectively, so that the hypothesis that $\alpha$ is equal to the actual share of labor camnot be rejected.

Other factors that failed to add significantly to the productivity relationships estimated earlier continue to be insignificant. These include adjustments for pollation abatement capital and the changing proportions of young people (age 16-19) or women in the labor force.

Finally, it remains the case that pre-1974 producfion function estimates that omit energy developments break down after 1973. When the 1949-73 model is estimated without the relative price of energy, the standard error of the equation is identical to that shown in table 3 . When the sample period is extended to 1975 and 1980 , the standard error of the equation withont energy rises to 1.24 percent and 1.37 percent, respectively. The Chow test indicates that a signficant change in the structure of the production function occurs in each case when energy is omitted and the sample period is lengthened. As the stability of the standard errors in table 3 indicates, such stuctural changes can be rejected using the Chow test when energy prices are included.

An estimate of the production function using quarterly data from II/1948 to III/1981 is:

(2) $\ln X_{t}=1.4688+0.7351 \ln h_{t}+0.2649 \ln k_{t}$ $(2) .03) \quad(23.81) \quad(8.58)$

$$
\begin{array}{cc}
-0.0893 \ln (\mathrm{Pe} / \mathrm{P})_{t}+ & 0.0045 \mathrm{t} \\
(-8.31) & (16.94)
\end{array}
$$

$$
\begin{array}{rrrr}
\overline{\mathrm{R}}^{2}=0.99 & \mathrm{SE}=0.0074 & \mathrm{DW}=1.96 & \hat{\phi}=0.76 \\
\hat{\mathrm{x}}=0.6748 & \hat{\beta}=0.2432 & \hat{\gamma}=0.0820 & \hat{\mathrm{r}}=0.0041 \\
(26.09) & (10.22) & (9.05) & (18.41)
\end{array}
$$

The estimated coefficients are essentially the same as those in table 3 . This quarterly production func- 
tion is used below to derive the revised potential output series. The stability and all other properties discussed above for the annual equations in table 3 apply to the quarterly estimates as well.

The impact of a change in the relative price of energy on output, productivity, real wages, and the capital stock can be assessed using the production function estimate in equation 2 . For a given employment of labor hours and capital services (the shortrun effect), a 10 percent rise in the relative price of energy reduces PBS ontput $\left(\mathrm{X}_{\mathrm{t}}\right)$ and productivity by 0.89 pereent. The long-run elasticity of output, labor productivity, real warges, and the capital stock is $(-\gamma / \alpha)$, or 0.122 in this case. ${ }^{6}$ Thus, a 10 percent rise in the relative price of energy leads to a long-rum decline in output that is 36 percent larger than in the short run. In particular, a 10 percent increase reduces output, productivity and the capital-labor ratio by 1.22 percent. From the third quarter of 1973 to the third quarter of 1974, and, again from the first quarter of 1979 to the second quarter of 1980 , the relative price of energy rose 40 percent. ${ }^{7}$ Given the estmates above, each shock reduced productivity and potential output by 3.6 percent in the short run and 4.9 percent after adjustment of the market for capital goods.

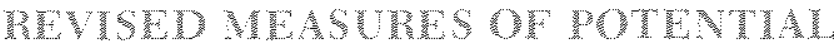

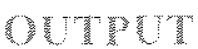

To determine potential real GNP, measures of potential employment of labor and capital are used to construct potential private business sector ontput. Other components of real GNP that are not sensitive to cyclical movements in output and are independent of the employment of labor are then added to obtain potential GNP. The latter components are the output originating in the rest of the world, general government, households and non-profit institutions.

\footnotetext{
"See John A. Tatom, "Energy Prices and Gapital Formation: 1972. 77," this Retew (May 1979), pp. 2.11, for an explanation and derivation of this result.

Note that percentage changes are neasued by the change in the logarithm of the relative price of energy. The exact magnitudes over the two periods are 40.7 percent and 40.3 percent, which measured as actul percentage increases are 50.2 and 49.6 percent, respectively. The relative price of energy rose azother 12 percent in the first half of 1981 due to the immediate elfects of domestic crude oil decontrol, but stbsequent adjustments in the world market die to decontrol took 2.8 percentage points off this in the third quarter of 1981 alone.
}

The deviation of actual from potential employ. ment of the nition's capital stock is based on an observation that at peak periods in the past, the Federal Reserve Board capacity utilization rate measure has been about 87.5 percent. This benchmark is used in the private business sector production function for full employment. ${ }^{8}$

The potential input of hours of all persons employed in the private business sector is found by determining potential hours per worker and potential employment. In each case, atctual measures are related to a measure of slack in the labor market. This slack measure (UN) is the unemployment rate of the civilian labor force (U), minus the full-employment unemployment rate of the civilian labor force (UF), which was prepared in 1977 for the Council of Economic Advisers $(\mathrm{UN}=\mathrm{U}-\mathrm{UF})^{9}$ Hours per worker in the private business sector are found from the regression of hours per worker on excess unemployment in the current and past quarter, a shift variable (D) to account for the unusually high levels of hours per worker from III/196I to II/1967, and a time trend $(t)$ to account for a secular decline in hours per worker. For the period II/1948 to III/1981, this equation is:

$$
\begin{aligned}
& \text { (3) } \ln \mathrm{HPW}=0.797-0.496 \mathrm{UN}_{t}+0.177 \mathrm{UN}_{\mathrm{t}-1} \\
& \text { (546.1) (-6.06) (2.16) } \\
& -0.001 \mathrm{t}+0.014 \mathrm{D} \\
& (-57.06) \quad(7.29)
\end{aligned}
$$

$\bar{R}^{2}=0.99 \quad \mathrm{SE}=0.0032 \quad \mathrm{DW}=1.89 \quad \hat{\rho}=0.62$

This equation has not been changed since 1977 , except for the addition of the significant lagged slack

St can be argued that, at these peaks, "nomal" operating com ditions for the nation's plant and emuipment are not observed and that, if demand were sustained, firms would increase investment to lower operating rates to optinal levels. In this gase an 87.5 percent ate for the FRB capacity utilization mate overstates the "natual rate" of anatity ntilization. This atgunent has been made in John A. Tatom, "The Meaning and Measurement of Potential Ontpit: A Comment on the Perloff and Wachter Results," in Kinl Brumer and Allan H. Meltzer, eds., Thee? Aspects of Palcumaking; Knoteledge, Data and hastitutions. Camegte-Rochester Conference on Public Policy, volume 10 (1979), pp. 165-78. The benchmark is supported by comparative movements in "excess" nnemployment of the civilian labor force and the capacity utilization rate. When the capacity utilization is regressed on the excess unemployment rate described in the text below over the period 1/1955-1//1981, the constant is 86.2 percent with a standiard enor of 0.78 percentage points when a significant lagged unemployment rate is included.

9This datas series and its development is tescribed by Peter $K$. Clark, "Potential Ontput in the United States 1948-80" V.S. Productive Capreity: Estinatinat the Ctilization Gap (Washington University: Center for the Study of American Business, December 1977), pp, 2I-66. 
term. ${ }^{10}$ The sum of the slack terms, -0.32 , is virtually identical to the single contemporaneous term in the earlier estimates, so that only the timing of the cyclical effect has been changed. Potential hours per worker is found from the predicted values of equation 3 with the slack variable set at zero in the current and past quarter.

Potential employment in the private business sector is found in a similar manner. In particular, the logarithm of private business sector employment (In $\left.\mathrm{EM}_{\mathrm{t}}\right)$ is regressed on a constant, a time trend $(\mathrm{T})$, excess unemployment in the current and past quarter, and a trend shift variable (T2) to account for a shift in the trend rate of growth of the labor force after 1964. This particular break in trend was chosen on the basis of the lowest standard enror of the equation. A break in trend is included to improve the efficiency of the estimation of the coefficients for the slack variables. The equation for the II/1948111/1981 period is:

$$
\begin{aligned}
& \text { (4) } \ln _{\mathrm{n}} \mathrm{EM}=3.94+0.002 \mathrm{~T}+0.004 \mathrm{~T} 2 \\
& (371.63) \quad(7.21) \quad(9.59) \\
& -0.013 \mathrm{UN}_{\mathrm{t}}-0.003 \mathrm{UN}_{\mathrm{t}-\mathrm{I}} \\
& (-11.03) \quad(-2.63)
\end{aligned}
$$

$\overline{\mathrm{R}}^{2}=0.91 \quad \mathrm{SE}=0.0046 \quad \mathrm{DW}=1.87 \quad \hat{\rho}=0.92$

When this equation is differenced, the autoregressive disturbances disappear (the Durbin-Watson statistic without first-order autocorrelation adjustment is 1.89), and the coefficients for the trend, break in trend, and slack variables are virtually identical. To find potential employment in the private business sector, the actual level of employment is cyclically adjusted by $\left(0.13 \mathrm{UN}_{\mathrm{t}}+0.003 \mathrm{UN}_{\mathrm{t}-1}\right)$ percent, according to the level and first difference equations. ${ }^{11}$

\footnotetext{
${ }^{10}$ This equation was explamed in Robert H. Rasche and Johm $A$ Tatom, "Potental Output and Its Growth Rate - the Dominance of Higher Energy Cost in the 1970"s," U.S. Productice Capucity: Estimating the Utilization Gap (Washington University: Center for the Study of American Business, December 1977, pp. 76-77. The umustal shift in hours per worker in the '60s has also been noted by George L. Perry, "Potential Ontput ind Productivity," Brookings Parers on Economic Acticity $\{1: 1977), \mathrm{pp} .11,-47$. Tests of additional lagged valnes of the excess zanemployneat rate found them to be insignificant.

${ }^{1}$ The elfect of ane percent rise in the excess unemployment rate on PBS employment should be roughly at percent decline equal to the ratio of the civilint labor force to PBS unemployment. This miy be derived from the relation thet PBS employment is (1 - U) LF - NE, where U is the wnemployment wate of the civilian labor force (LF), and $N E$ is non-PBS employment, measured by the difference in civilian emplowment and PBS employment. The actual rutio of the labor fore to PBS employ-
}

This method of determining potential employ ment differs from the one this Bank used earlier. Until recently, potential PBS employment was found by subtracting the level of current employment outside the private business sector from potential civilian employment $\left[\left(1-U_{F}\right)\right.$ times the civilian labor forcel. The former was equated to the difference in actual civilian employment and PBS employment. This method had two minor shortcomings. First, periodic census revisions and changes in sampling and estimation methods alter the civilian labor force and employment data, slightly affecting a measure such as the above and an accompanying measure of potential output. Second, this employment measure was somewhat cyclical, despite the absence of any permanent cyclical effects on the civilian labor force measure. The reason for this appears to be that PBS employment and civilian employment data are estimated by different methods, and their difference is cyclical. ${ }^{12}$

Revised quarterly estimates of potential real GNP are presented in the appendix to this article. These data as well as actual real GNP are shown in chat 2. The growth rate of this revised potential output series has been unchanged for past periods. The average growth rate of potential output was 3.7 percent from 1949 to 1973 , the same as in the original estimates. This rate has varied somewhat in the past, however, largely reflecting differences in the growth rate of the labor force. For example, from 1951 to 1963, potential output grew at a 3.3 percent rate while the civilian labor force grew at only a 1.2 percent rate. Potential output growth accelerated to a 4.0 percent rate from 1963 to 1973 , as labor force growth accelerated to a 2.1 percent rate.

Since 1973 , the potential grow th rate has averaged 3.1 percent despite a labor force growth of 2.4 percent. The potential output growth rate has been as high as 5.0 percent in 1977-78. The annual growth rate of potential output in 1974 and 1980 was only 2.0 percent; in 1975 , this growth rate was only 2.6 percent. These relatively slow rates reflect the impact

ment in the sample period has a mean of 1.26 . The remainder is due to cyclical variation in non-PBS employment that does not affect non-PBS ontput.

${ }^{12}$ The difference between establisment-basted payol measues of employment and households-sampling-based civilian employment meisures is procydical so that the old method resulted in at measure of potential PBS employment that was inversely related to excess memployment. This cyclical difference is discussed by Alexander Korns, "Gycleal Fluctuations in the Difference Between Payroll and Household Measures of $\mathrm{Em}$ plovment," Surtey of Current Business (May 1979), 13p, 14-44. 
Chart 2

\section{Real GNP}

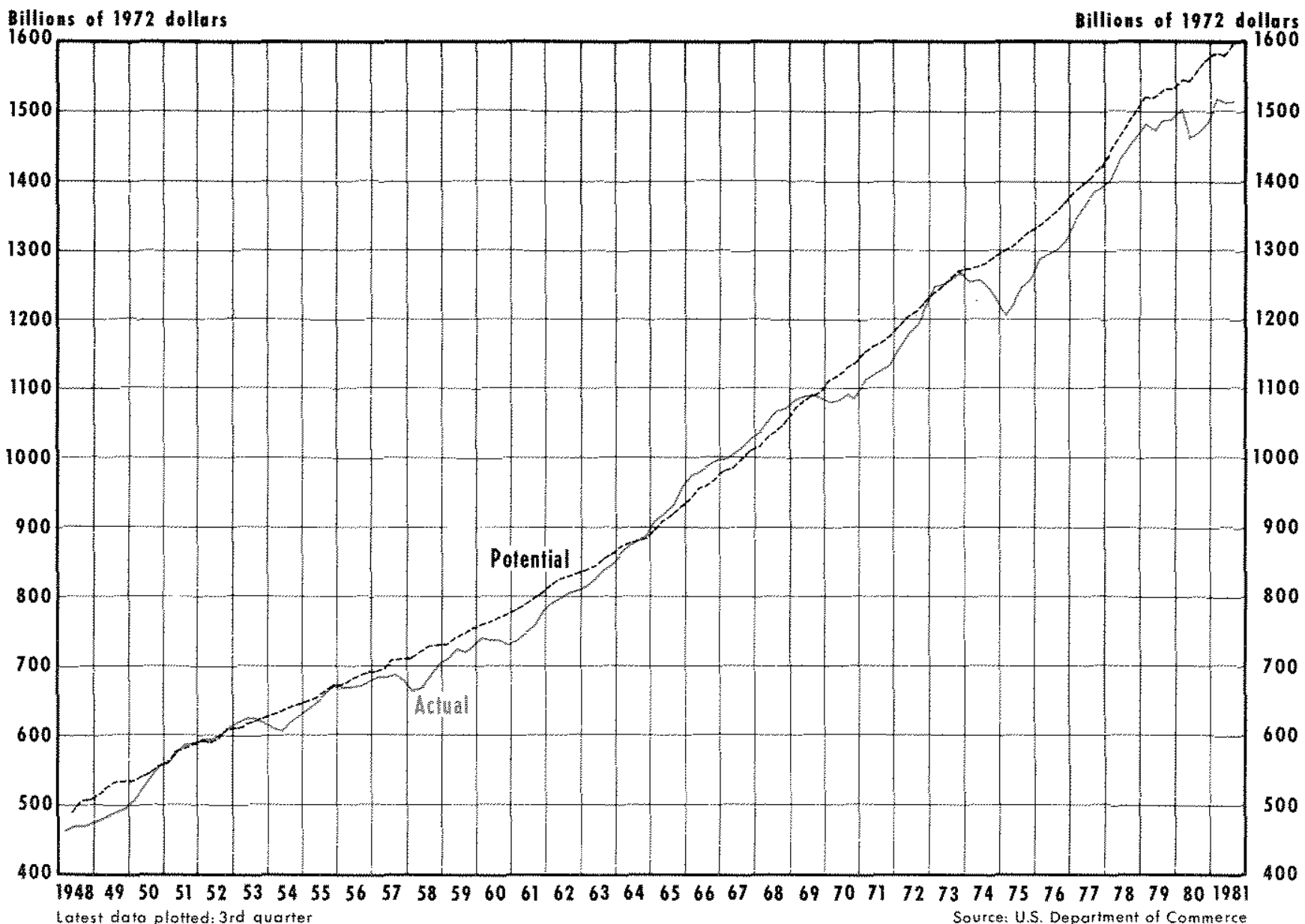

of sharp increases in the relative price of energy resoluces.

Table 4 shows the annual averages of recent levels of potential GNP together with recent estimates by the Council of Economic Advisers (CEA). ${ }^{13}$ The CEA estimates range from 1.4 percent below to 1.0 percent above those presented here. The percentage difference between the two measures is virtually the same in 1973 as reported earlier, but the 1977 CEA estimates for the period 1974.76 rose from 1.1 percent larger to almost 3 percent larger than this Bank's estimates. The two estimates are now extremely close, largely due to major revisions in the CEA

1:See Council of Econonic Advisers, Economit: Report of the Prosident, 1981. estimates reported in the Economic Report of the Prosident in 1977 and 1978 . These revisions pushed the 1973 level below that estimated by this Bank, but then assumed a roughly constant growth rate that was laster in 1974-76, then slower in 1976-79, than that estimated here. The CEA reported in 1981 that potential output was expected to grow at a 2.9 percent rate in 1979 and 1980 , then retum to a 3.0 percent rate. ${ }^{14}$

The CEA estimate is apparently based thon the expeckation that the labor force will grow at a 1.75 percent rate, hours per worker will decline at zeculat rate of 0.5 percent and that potential productivity (output per hour will rise at aloout at 1.75 percent rate. See Economic Rewort, 1980 , pl. $89-90$ and Economic Report, 1981, pp. 180-81. Such a ate of productivity advance niay appeatr optimistic in light of the experience since 1978 or in $1973-75$. It should be noted, however, that potential 
Table 4

Recent Measures of Potential GNP (billions of 1972 dollars)

\begin{tabular}{|c|c|c|c|}
\hline & Potental onP & $\mathrm{CEAeSt} / \mathrm{mate}$ & noto \\
\hline 1973 & 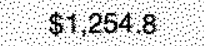 & 82349 & $98,3 \%$ \\
\hline 1974 & 12797 & 1275 & 998 \\
\hline 1975 & 13130 & 1,3206 & 100,6 \\
\hline 1976 & 1,3518 & 13651 & 1010 \\
\hline 197 & 14000 & 14144 & 1008 \\
\hline 1978 & 4700 & 14590 & 993 \\
\hline 1979 & 15262 & 15046 & 906 \\
\hline 1980 & 15662 & 15485 & $\$ 95$ \\
\hline
\end{tabular}

The primary difference shown in table 4 is that the CEA growth rate of potential output of 3.4 percent in 1973-76 exceeds the 2.5 percent rate estimated here, while its growth rate for 1976.79 of 3.3 percent is less than the 4.1 percent rate estimated here. It appears that, in recent years, the CEA has smoothed its potential output series to capture the sharp supply shock effects on potential output by lowering the growth rate of potential output over several years. As a result, the levels of potential output have not differed substantially. This difference is to an extent intentional, as the CEA has always employed a given growth rate for long periods. This tendency has been tempered in recent years, as can be seen by the slight variability in the CEA annual growth rate shown in table 4 . It may be that the $1980-81$ productivity losses that result from energy shocks will be largely reflected in the CEA's use of too slow a rate of potential growth for the early 1980s.

\section{PECWNT ACTUALABD POTRNTHL PRODUCTIVIT DEVELOPMINTS}

The sharp drops in potential output growth in 1974-75 and 1980 reflect the effect of major energy price changes on actual and potential productivity.

output per hour, discussed in the next section, rose over fiveyear periods at no less than at 2.5 percent rate from $1948-73$. Following the implementation of accelerated clepreciation and corporate tax cuts, the pace of capital formation rose sharply so that it surged to the post-World War II peak rate of 3.2 percent from 1963 to mid-1970. Even during 1978 potential productivity growth had risen to over a 2 percent rate as the adjustment to the prior energy shock was apparently approaching completion. A repeat of thit pattem and recent supply-side policies suggest a more napid pace of productivity growth from 1982-85 than that projected by the CEA.

\section{Table 5}

\section{Recent Productivity Developments (compound annual rates)}

\begin{tabular}{|c|c|c|c|}
\hline & $\begin{array}{l}\text { W/948 } \\
\text { W/1973 }\end{array}$ & $\begin{array}{l}\text { W/973 } \\
\text { W/1980 }\end{array}$ & bifference \\
\hline Growth ol outputhour & $2.87 \%$ & $0.67 \%$ & 220 \\
\hline Potential growth ate & 282 & 094 & 188 \\
\hline eyclical arclors & 0.09 & 020 & 029 \\
\hline Aestdual tactors & 1004 & 007 & 003 \\
\hline \multicolumn{4}{|l|}{$\begin{array}{l}\text { Contribution to potential } \\
\text { growth rate of }\end{array}$} \\
\hline Capital accumulation & 0.92 & 0.28 & 0.64 \\
\hline $\begin{array}{l}\text { lorowth la ligh-employment } \\
\text { caplat labor rallol }\end{array}$ & $(352)$ & $(104)$ & (248) \\
\hline Eliergy price changes & 0.07 & $-1 / 3$ & 120 \\
\hline
\end{tabular}

Since 1973, productivity's abysmal performance has been a major concern for policymakers. Thus, it is useful to detail the factors infuencing such growth over the last seven years. ${ }^{15}$

An analysis of the actual and potential productivity decline for the private business sector appears in table 5, where growth rates and the contribution of various factors are compared for two periods: 1948 to the end of 1973, and 1973 to the end of 1980. Output per hour grew at a 2.87 percent rate from IV/1948 to IV/1973, then slowed to a 0.67 percent rate over the next seven years. This growth can be analyzed in two ways. The first is to look at the contribution of the factors entering equation 2 : the actual changes in the growth of employed capital relative to labor, the relative price of energy, the pace of technological change, and residuals due to random errors of fitting the equation at the end points of the period. The second, shown in the top panel of table 5 , is to break down actual productivity growth in each period into changes due to the growth of potential productivity, changes due to cyclical variations in the employment of capital and labor at the beginning and end periods, and differences in the residual or random error component of equation 2.

\footnotetext{
${ }^{15}$ Tn contrast to Edward F. Denison, "Explanations of Declining Productivity Growth," Surey of Current Business, (August 1979 , part 2), pp. 1-24, the andysis bere of post-1973 productivity developments filly explains the prodmtivity "puzzle," while other explanations do not. See "Tatom, "The Productivity Problem" or especially Denison's papez for a discussion of these other fictors. The puzzle is prestmably all the more challenging to other analysts due to the post-1978 cessation of productivity growth.
} 
Chart 3

\section{Capital Labor Ratio (Private Business Sector)}

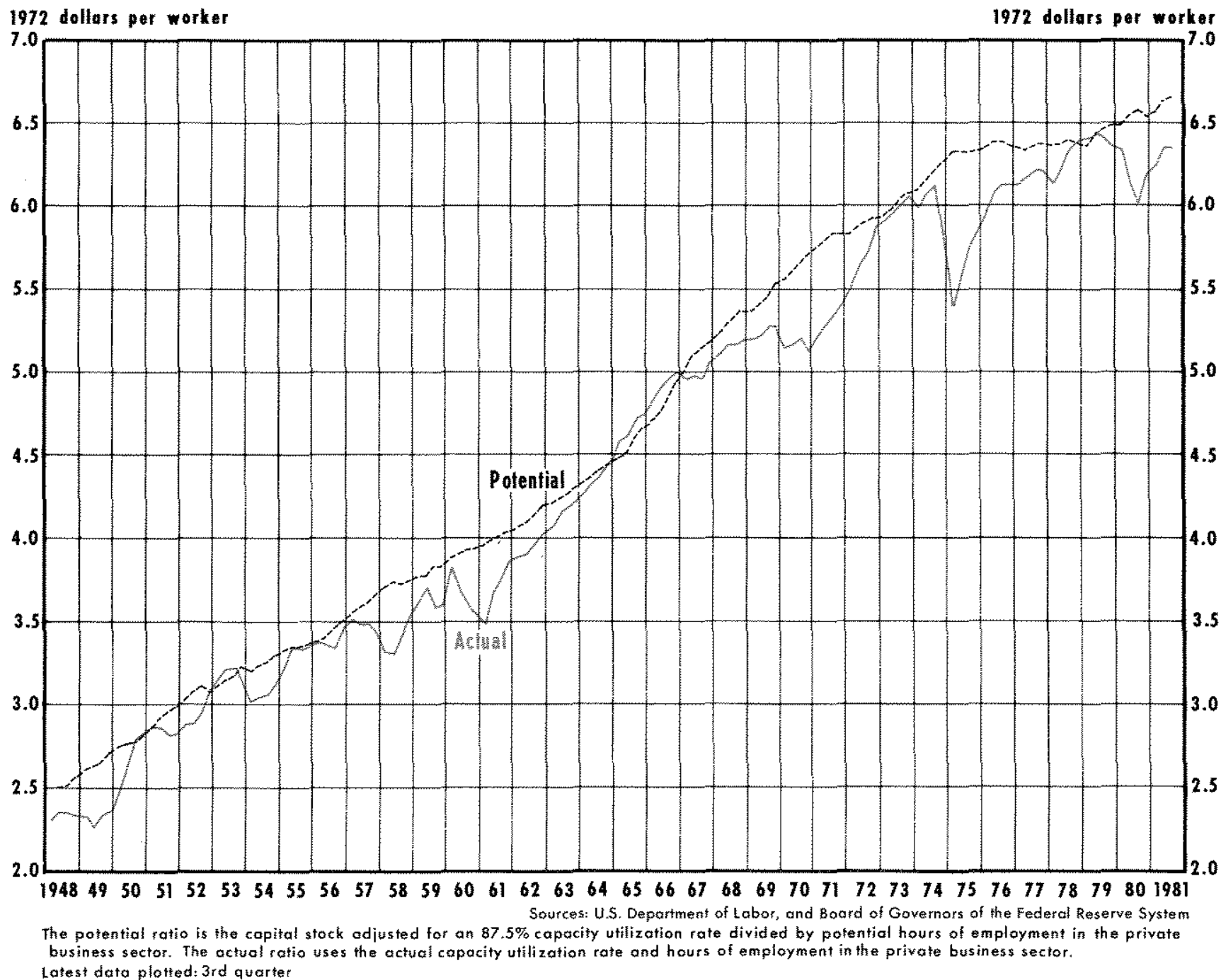

The contribution of cyclical factors accounts for the difference between the productivity effect of the growth of the potential PBS capital-labor ratio (the contribution of the capital-labor ratio to potential growth) and the effect of the actual growth in the utilization of capital per hour. The discrepancy between the two arises from the cyclical variability of the capital-labor ratio shown in chart 3 . The sum of the "cyclical factor" and the contribution of "capital accumulation" to potential productivity growth indicates the estimate of the actual impact of movements in the observed ratio of utilized capital to labor hours on the observed productivity growth.
Most of the 2.2 percentage-point decline in productivity growth over the last seven years has been due to factors that slowed potential productivity growth. For the particular comparison shown, cyclial differences between productivity movements in the two periods or residual errors account for only 0.3 percentage points of the observed slowing.

In the lower part of the table, the factors contributing to the potential productivity grow th slowdown are shown. What is omitted in the lower part of the table is the trend growth of total factor productivity which contributed 1.82 percentige points to the rate 
Chart 4

\section{Potential and Actual Output per Hour (Private Business Sector)}

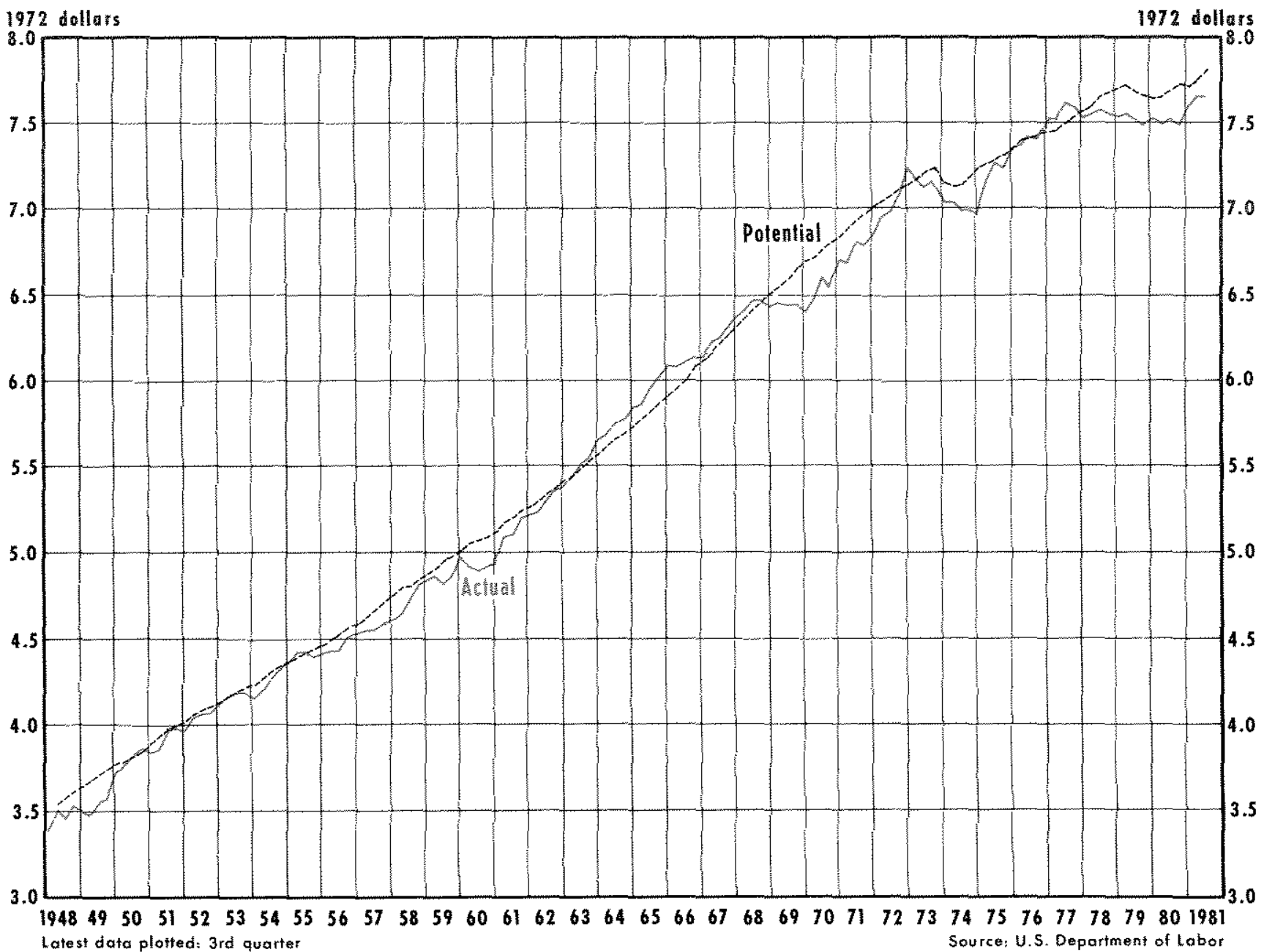

of productivity growth in both periods. The direct effect of energy price shocks over the last seven years has been to reverse the slight positive contribution of energy price declines over the prior 25 years, so that 1.20 percentage points of the 1.88 percentage-point-per-year decline in potential productivity growth has been dae to this factor. The remainder has been due to a slowing in capital formation.

As noted in parentheses, the growth rate of the capital stock relative to potential hours of employment was 3.52 percent over the 25 years ending in 1973; subsequently, this growth slowed to about one percent. This slowing reduced the contribution of capital formation from a 0.92 percent rate to a 0.28 percent rate over the last seven years. When this result is combined with the effect on productivity growth of cyclical movements in the capital-labor ratio, the result is that capital formation, which added 1.01 percentage points $(0.92+0.09)$ to the atctual pace of productivity growth from the end of 1948 to the end of 1973 , only contributed 0.08 percentage points to the actual rate of productivity growth from the end of 1973 to the end of 1980. Implicitly, cyclical differences between the end of 1973 and 1980 offset the effect of growth in capital per hour, so there was virtually no change in the actual employment ratio.

The small changes in table 4 become quite large when compounded over the seven-year period. For example, the slowing in the potential growth rate over the seven-year period reduces private sector 


\section{Chant 5}

\section{Real GNP per Civilian Worker}

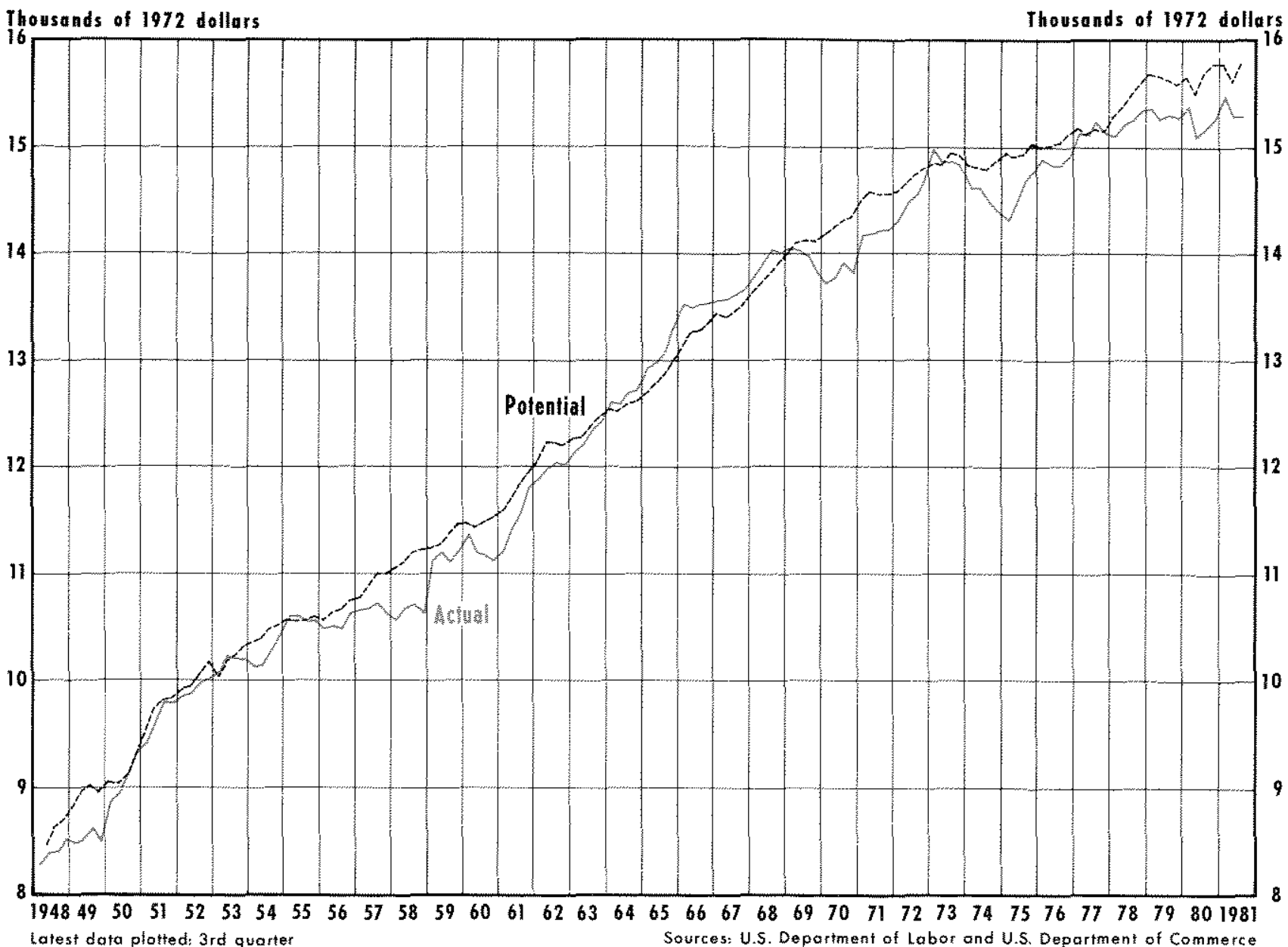

output by 13.8 percent by the end of 1980 . "The direct impact of energy price increases alone over these seven years reduces output by 8.3 percent.

Moreover, a large share of the reduction in capital formation since 1973 has been due to energy price developments. The inclusion of the energy pricem induced slowing in the desired capital-labor ratio leads to an 11.5 percent loss in output. The remaining loss in potential productivity is associated with a non-energy-related slowing in capital formation. ${ }^{16}$

\footnotetext{
${ }^{16}$ Factors responsingle for the cessation of growth in the atilized catpital-iabor ratio besides the dectine in the prodrativity of cuptal due to energy price changesand monor yolical infuences, include sud factors as higher expected inflation, inflition tuncertanty, and riskier retums due to an increased probability of govemmental intervention though regulatory initiatives. See Tatom, "The Productivity Problem," Patric H. Hendel-
}

Finally, it should be noted that table 5 presents a summary view of the effect of energy price changes on actual and potential productivity that does not reflect the actual pattem of events. In particular, the "slowdown" described in table 5 is not continuous. Associated with each energy shock is ance-and-forall decline in both measures of productivity, with

shot, "The Decline in Aggregate Share Values, Taxation, Valuation Forrors, Risk, and Profitability," Anerican Ecomomic: Rovec (December 1981), pro 909-22, discusses these and other factors that contribute to the slowdown in capital formation and argaes that inflation alone hats lat little mpact on the decline in share values and implicitly, capital formation. Instead he clams that a change in risk premins attributed to inoreased nocertanty abont price and regulatory changes in equity ard bond yieks and reduced pretax proftabitity have ben the reatson for about half the dedine in share values. Hendershot does not assess the role of at higher relative price of energy in reducing the pretax real profitability of the corporate cupital stokk. 
temporarily slower growth as the capital-labor ratio is adjusted toward a lower desired level. This pattern is more clearly apparent in chart 4, which shows potential and actual measures of private business sector ontput per hour. Deviations in the two are predominantly due to the business cycle. The pattem of potential productivity developments in chat 4 shows virtually no growth from mid-1973 to mid1975 and relatively slow expansion from mid-1975 to mid-1977. Following the second energy shock, potential productivity fell, then was virtually unchanged until the end of 1980 . The second phase of a relatively slow pace of potential productivity expansion is apparent in the first three quarters of 1981 .

Chart 5 shows an alternative measure of productivity, real GNP per civilian worker, again measured on both an actual and a highemployment basis. it The primary diflerence from chat 4 is the secular rate of decline in hours per worker. Both actual and potential real GNP per worker have flattened out twice relative to the prior trend growth, with a resumption of growth from early 1977 until early 1979. At the end of 1980, potential real GNP per

\footnotetext{
TThe highenployment measure of civilian employment is found by regressing clanges in the logarith of the civilian fabor force on al constant, it shift for faster abor fore growth after 1964 and curent and one-lagged changes in the exeess unemployment Fate, Aditional lags are not statistically significant. Morewer, the constuint that the effect of slack is zero after two quaters could not be aefected. The effect of a one percentage-point increase in slack is to increase the labor forte by 0.2 percent $t=$ 2.34) in the current quater and this is offet in the swhequent Guarter. To find the high-enployment civilat employment, these oyticat effects are added back to the observed civiliat labor force and high-employment memployment (UF) (L.F') is removed.
}

worker stood only 5.7 percent higher than at the end of 1973 , so that five years worth of the prior trend growth ( 2.2 percent rate) has been lost during the past seven-year period.

\section{SUMMANY}

Recent revisions in the measures of the nation's output and capital stock, as well as minor changes in procedures, have altered this Bank's measures of potential output. The major conclusions of earlier Bank studies, however, have been inaffected by these changes. In particular, the growth of potential output has been sharply reduced by the 1973-74 and 1979-80 energy shocks and subsequent adjustments in the desired capital in tensity of production. These effects have been confimed by the re-estimation of earlier production function coefficients, and, more important, the confirmation of the prior empirical estimates in the latest round of energy price increases.

The decline in the grow th of potential output since 1973 has, in recent years, been acknowledged by the Council of Economic Advisers, but through a trend reduction rather than through sharp temporary declines in 1974-75 and $1979-80$ as implied here. Nonetheless, the level of potential output estimated by the CEA in recent years is little different from this Bank's estimate. The slowing in potential output masks a shaper reduction in the growth of productivity in recent years. A detailed analysis of productivity developments shows a marked deterionation in growth relative to past trends. In the measurement of potential output, this deterioration has been partially offset by a more rapid growth of both potential and actual employment.

\section{(See appendix on next page)}




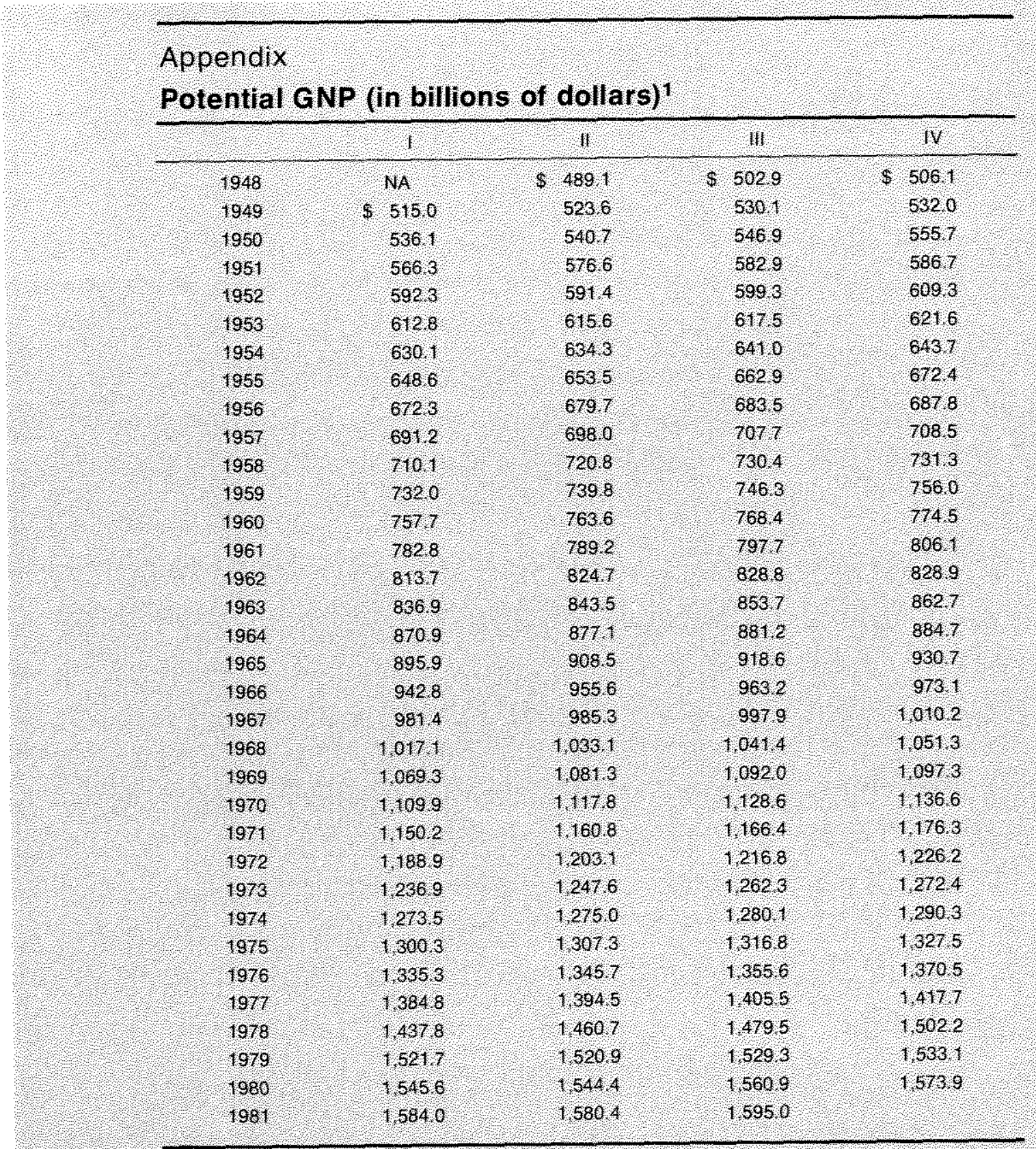

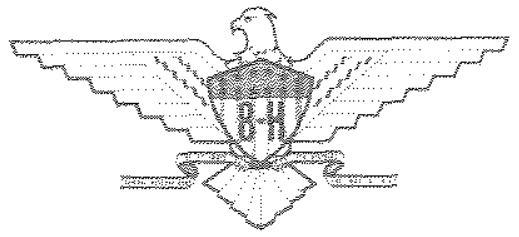

